\title{
Freezing injury in primary and secondary needles of Mediterranean pine species of contrasting ecological niches
}

\author{
Jose Climent $^{1 *}$, Filipe Costa E Silva ${ }^{2}, \mathrm{M}^{\text {a }}$ Regina CHAMbel $^{1}$, Marta PARdos $^{1}, \mathrm{M}^{\mathrm{a}}$ Helena AlmeIdA $^{2}$ \\ ${ }^{1}$ Forest Research Centre (CIFOR)-Instituto Nacional de Investigación y Tecnología Agraria y Alimentaria (INIA), Ctra. A Coruña km 7.5, \\ Madrid 28040, Spain \\ ${ }^{2}$ Instituto Superior de Agronomia, Tapada da Ajuda 1349-017 Lisbon, Portugal
}

(Received 28 October 2008; accepted 7 December 2008)

\author{
Keywords: \\ freezing / \\ electrolyte leakage / \\ frost / \\ ontogeny / \\ heteroblasty
}

\author{
Mots-clés : \\ gel / \\ perte d'électrolyte / \\ gelée / \\ ontogénie / \\ hétéroblastie
}

\begin{abstract}
- Pine seedlings show a marked ontogenetic difference between primary and secondary needles, the latter prevailing with a different timing among species.

- Using the electrolyte leakage method following an artificial freezing test, we aimed at (1) determining the differences in freezing tolerance between primary and secondary needles in eight pines of contrasting thermal habitats: P. canariensis, P. pinea, P. halepensis, P. brutia, P. pinaster, P. nigra, $P$. sylvestris and $P$. radiata, (2) evaluating the relation between freezing tolerance and sclerophylly and (3) relating freezing tolerance with the climate of origin.

- Primary needles were significantly more sensitive to freezing than secondary needles in Pinus halepensis, $P$. brutia, P. pinaster and P. nigra, whereas no differences were found in $P$. canariensis, $P$. pinea and $P$. radiata. LT50 was uncorrelated with needle sclerophylly but very highly correlated with the mean temperature of the coldest month at the seed source.

- Results support an adaptive role of secondary needles in the mountain Mediterranean pines P. nigra, $P$. pinaster and $P$. brutia, while the more complex responses in coastal Mediterranean pines can be interpreted in the light of seedling ontogeny and species' ecological niches.
\end{abstract}

Résumé - Dégâts du gel sur des aiguilles primaires et secondaires chez différentes espèces de pins méditerranéens dans des niches écologiques contrastées.

- Les jeunes plants de pin présentent une nette différence ontogénétique entre aiguilles primaires et secondaires, les secondes devenant dominantes après des délais variables selon les espèces.

- À l'aide d'une expérience de gel artificiel et à l'aide de la méthode de perte d'électrolyte, nous avons visé à : (1) déterminer les différences de tolérance au gel entre aiguilles primaires et secondaires de huit espèces de pins présentant des habitats thermiques contrastés : $P$. canariensis, $P$. pinea, $P$. halepensis, $P$. brutia, $P$. pinaster, $P$. nigra, $P$. sylvestris et $P$. radiata, (2) évaluer la relation entre tolérance au gel et degré de sclérophyllie, et (3) mettre en relation tolérance au gel et climat d'origine.

- Les aiguilles primaires étaient beaucoup plus sensibles au gel que les aiguilles secondaires chez Pinus halepensis, $P$. brutia, $P$. pinaster et $P$. nigra, alors qu'aucune différence n'a été constatée chez $P$. canariensis, $P$. pinea et $P$. radiata. La température induisant $50 \%$ de mortalité n'était pas corrélée avec la sclérophyllie des aiguilles mais très fortement avec la température moyenne du mois le plus froid de la provenance des semences.

- Les résultats corroborent l'idée d'un rôle adaptatif des aiguilles secondaires des pins méditerranéens montagnards $P$. nigra, $P$. pinaster et $P$. brutia, tandis que les réponses plus complexes des pins méditerranéens côtiers peuvent être interprétées à la lumière de l'ontogénie des semis et des niches écologiques des espèces.

\footnotetext{
*Corresponding author: climent@inia.es
} 


\section{INTRODUCTION}

While drought is considered as the main environmental constraint in Mediterranean ecosystems, frosts can be equally or more determinant in some areas, therefore cold hardiness of Mediterranean plant taxa has been a matter of concern for decades (Boorse et al., 1998; Larcher, 2000). Frost stress largely affects plant distribution, linked to contrasting life histories at a global and regional scale (Sakai and Larcher, 1987). Interactions between frosts and drought have attracted attention due to the ecological and evolutionary significance of these phenomena, in the framework of ongoing climate changes (Blodner et al., 2005; Palacio et al., 2005).

Given that the first years are critical for the establishment of long-lived woody plants, differential responses to extreme temperatures in early developmental stages are likely to be subjected to strong directional selection within each species' ecological niche (Meza-Basso et al., 1986). However, the different susceptibility to frosts of seedlings and adults does not follow a common pattern in woody plants. Postulations that juveniles should be more frost resistant than their mature forms were based on the fact that cold air usually accumulates near the ground (Darrow et al., 2001). But in fact, the temperature gradient of air from the soil to upper levels differ sharply depending on the predominant cause of frost, either radiation or advection, well documented in bioclimatic research (Taylor, 1970). In different woody plants there are examples of higher frost tolerance in juveniles (Bannister et al., 1995; Meza-Basso et al., 1986), in adults (Boorse et al., 1998) or no difference, as reported for Pinus radiata (Greer et al., 1989). Furthermore, the presence of sharp heteroblastic differences in the shoot development of young plants in some species adds further complexity - but also interest- to the comparison of the ontogenetic adaptive differences between juveniles and adults (Darrow et al., 2001; Jones, 1999; Winn, 1999). However, there is an almost complete lack of scientific literature on the comparison of frost damage between juvenile and adult leaf forms in heteroblastic woody plants, with the exception of the already mentioned work for New Zealand's woody angiosperms (Darrow et al., 2001).

In particular, we were intrigued about how differently juvenile (primary) and adult (secondary) needles of pine seedlings respond to freezing, to help understanding the adaptive role of the marked heterophylly in this genus. The retention of primary needles for several years and a delayed formation of secondary adult needles is a typical feature of Mediterranean pine seedlings (Klaus, 1989). Conversely, Eurosiberian pines such as $P$. sylvestris show a much faster ontogeny with secondary needles forming at the end of the first vegetative period and a subsequent senescence of primary needles. Secondary needles have been shown to have significantly lower specific leaf area (hence higher sclerophylly) than primary needles (Climent et al., 2006; Pardos et al., 2008). Since sclerophylly may provide resistance to frost damage delaying the propagation of ice in tissues with densely lignified or cutinized barriers (Larcher, 2005), it is worth to know if different levels of freezing injury between primary and secondary pine needles can be partly explained by their different degree of sclerophylly.
Climate change scenarios for the Mediterranean region, namely Iberian Peninsula foresee an increase in extreme events (IPCC, 2007). Unusual frost stresses might lead to unfitted responses of Mediterranean pine species due to atypical conditions in their ecological niches; therefore, a better comprehension of the developmental processes implied in stress tolerance is mandatory to predict the performance of Mediterranean pines under new environmental conditions and to improve evolutionary and growth models.

Through an artificial freezing test in excised needles of seedlings of eight wide sense Mediterranean pine species from contrasting thermal habitats, our aim was to (1) determine the differences in freezing tolerance between primary and secondary needles within each species (2) evaluate the relation between freezing tolerance and leaf mass area (LMA) as a proxi to needle sclerophylly (and 3) relate freezing tolerance values for both primary and secondary needles of each species with their climate of origin.

\section{MATERIAL AND METHODS}

\subsection{Plant material}

Plant material was obtained from seedlings of eight pine species, sharing a circum-Mediterranean geographical distribution area in Western Europe. Five of these were Mediterranean pines sensu-stricto (P. canariensis; P. pinea, P. halepensis, P. brutia and P. pinaster), two were Eurosiberian species ( $P$. nigra subsp. salzmannii and $P$. sylvestris) and one, $P$. radiata, was a representative of another Mediterranean Climate Zone. This species is naturally from California, although currently widespread in mild temperate regions worldwide (Shelbourne et al., 1979). Considering the published evidences of high intraspecific adaptive variation in most of the species (e.g. (Alía et al., 1997) for Pinus pinaster; (Bariteau, 1992) for P. brutia and P. halepensis; (López et al., 2007) for P. canariensis; (Savolainen et al., 2004) for P. sylvestris and (Shelbourne et al., 1979) for P. radiata), each species was represented by a single provenance corresponding to its central ecological range (Tab. I).

Seed lots consisted of an equilibrated mixture from 25 to 30 openpollinated mother trees taken in natural stands (except for $P$. radiata). Climatic variables were obtained for each provenance studied from the Global Climatic Model WorldClim v. 1.3 (Hijmans et al., 2005) implemented in DIVA-GIS at a 1-km spatial resolution. We chose the mean temperature of the coldest month and the yearly mean temperature in the interval 1950-2000 to characterize each provenance (Tab. I).

Previous to germination, seeds were stratified at $4{ }^{\circ} \mathrm{C}$ for a month to homogenize the germination velocity. In June 2005 seeds were sown in commercial $7 \mathrm{~L}$ containers with a mixture peat and perlite (3:1 v:v) plus $2 \mathrm{~g} \cdot \mathrm{L}^{-1}$ of slow-release Osmocote fertilizer for conifers. Irrigation was controlled to maintain water availability at about $80 \%$ of field capacity, corresponding to $37 \%$ in volume. Seedlings were grown in a greenhouse at North-West Spain $\left(42^{\circ} 16^{\prime} 38^{\prime \prime} \mathrm{N}, 7^{\circ} 37^{\prime}\right.$ 32 " W, $537 \mathrm{~m}$ a.s.1.) under natural photoperiod and carried outdoors in February before the second vegetative period. Containers were embedded in perlite to avoid excessive temperature oscillation of the rooting media. Plants were naturally acclimated to outdoors air temperatures, which were monitored during the months previous to the artificial freezing test (Fig. 1). On December 10, six plants per species 
Table I. Geographic location of the studied provenance (seed source) for each species. Altitude, mean annual temperature (MAT) and mean temperature of coldest month (TCM) corresponding to the geographical centre of the provenance.

\begin{tabular}{|c|c|c|c|c|c|c|}
\hline Species & Provenance & Latitude & Longitude & Altitude & MAT $\left({ }^{\circ} \mathrm{C}\right)$ & TCM $\left({ }^{\circ} \mathrm{C}\right)$ \\
\hline P. brutia & Taurus (Bucak) & $37^{\circ} 29^{\prime} \mathrm{N}$ & $30^{\circ} 37^{\prime} \mathrm{E}$ & 980 & 13.5 & 3.9 \\
\hline P. canariensis & Tenerife & $28^{\circ} 19^{\prime} \mathrm{N}$ & $16^{\circ} 44^{\prime} \mathrm{W}$ & 1350 & 14.8 & 10.3 \\
\hline P. halepensis & Inland Eastern Spain & $39^{\circ} 35^{\prime} \mathrm{N}$ & $0^{\circ} 58^{\prime} \mathrm{W}$ & 830 & 13.7 & 5.5 \\
\hline P. pinea & La Mancha & $39^{\circ} 22^{\prime} \mathrm{N}$ & $2^{\circ} 38^{\prime} \mathrm{W}$ & 690 & 14.3 & 6.3 \\
\hline P. pinaster & Guadarrama Mnts. & $40^{\circ} 34^{\prime} \mathrm{N}$ & $4^{\circ} 19^{\prime} \mathrm{W}$ & 1230 & 12.7 & 3.2 \\
\hline P. nigra & Southern Iberian Range & $40^{\circ} 43^{\prime} \mathrm{N}$ & $2^{\circ} 15^{\prime} \mathrm{W}$ & 1280 & 10.3 & 2.2 \\
\hline P. sylvestris & Guadarrama Mnts. & $40^{\circ} 51^{\prime} \mathrm{N}$ & $4^{\circ} 00^{\prime} \mathrm{W}$ & 1520 & 11.0 & 2.0 \\
\hline P. radiata & Vasque Coast & $43^{\circ} 15^{\prime} \mathrm{N}$ & $2^{\circ} 05^{\prime} \mathrm{W}$ & 220 & 13.0 & 7.5 \\
\hline
\end{tabular}

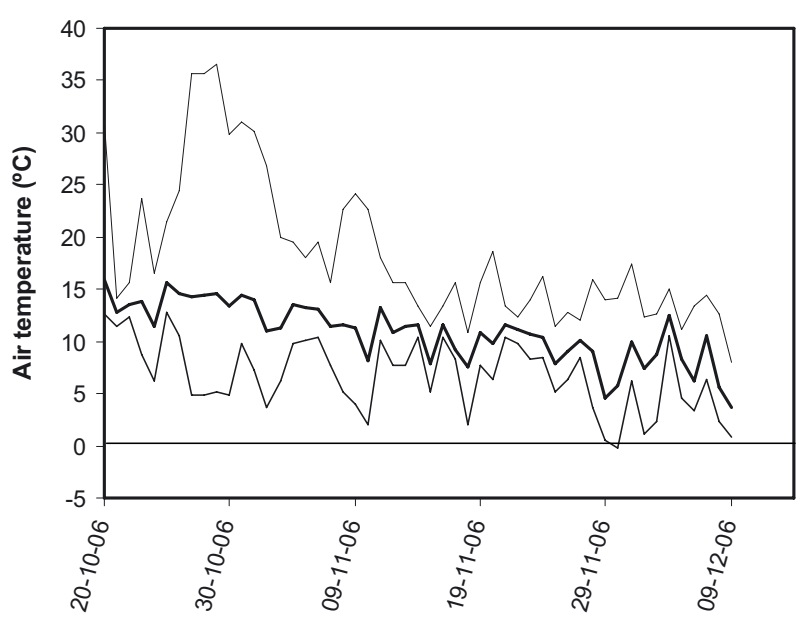

Figure 1. Air temperature at the nursery prior to the freezing tests: daily maxima and, minima (thin lines) and mean temperature (bold line).

were transported to ISA laboratory in Lisbon where the freezing test took place.

The ontogeny of the eight studied species varied greatly from the much delayed Mediterranean species (especially P. canariensis, $P$. pinea and $P$. halepensis) to the much faster Eurosiberian species (Pardos et al., 2008). We therefore chose an strategic seedling age, 18 months, such that most species had developed dwarf shoots with secondary needles in the axils of primary needles (transitional vegetative metamers) while juvenile needles were still healthy (Fig. 2). However, this was not totally possible, and while seedlings of $P$. $\mathrm{Ca}$ nariensis had only produced a few secondary needles, most primary needles of $P$. sylvestris were already senescent; therefore, in this last species only secondary needles could be assessed.

\subsection{Needle sampling and preparation}

Tests were held on two types of needles: primary $(\mathrm{P})$ and secondary (S) needles. All samples were taken randomly from adjacent stem portions of the same individuals in order to minimize possible ontogenetic difference on a plastochron basis (Erickson and Michelini, 1957), but ensuring that secondary needles had completed their development in the nursery on the outside conditions.

All freezing tests were performed on six plants per species. Samples were prepared from two secondary needles or 10 primary nee-

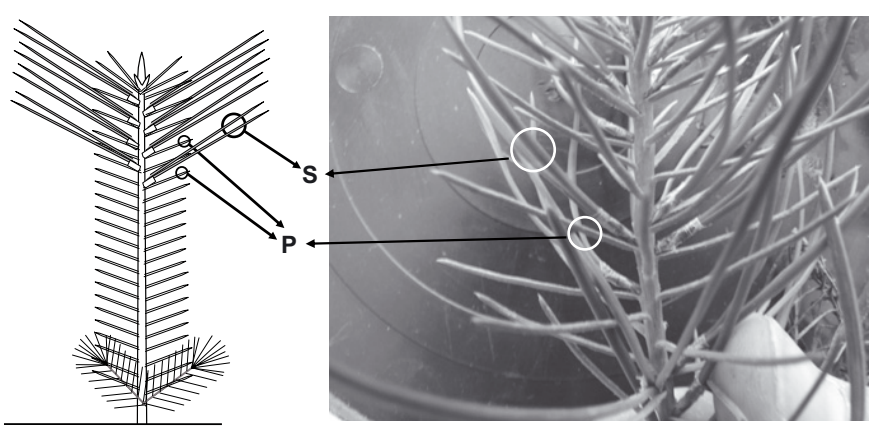

Figure 2. Position of primary $(\mathrm{P})$ and secondary $(\mathrm{S})$ needles in the studied seedlings. The photograph corresponds to an individual of $P$. pinaster.

dles per plant cut to approximately equal sizes $(15 \mathrm{~mm})$, discarding tip and basal portions. For each seedling, two samples of fifteen needles (primary and secondary) were used to determine Leaf Mass Area (LMA) calculated as the needle dry mass per needle area $\left(\mathrm{g} \cdot \mathrm{cm}^{-2}\right)$, as a proxi to needle sclerophylly. Projected needle area was determined by scanning and applying the software WinFolia2002a (Régent Instruments Inc., Switzerland) and dry mass was obtained after oven-drying needle samples for $24 \mathrm{~h}$ at $70{ }^{\circ} \mathrm{C}$.

\subsection{Artificial freezing test}

Needle samples from six seedlings per species were introduced in test tubes and racks of test tubes were placed inside a controlled freezer (Aralab, Lisbon, Portugal) in baths containing an aqueous ethylene glycol solution. An unfrozen control sample was kept at room temperature for each individual and needle type tested. To avoid supercooling, approximately $0.5 \mathrm{~g}$ of finely crushed ice (from deionised water) was added to each tube as soon as the temperature was negative to make contact with needle parts. A controlled freezing program followed a constant cooling and thawing rate of $2{ }^{\circ} \mathrm{Ch}^{-1}$ and a $4 \mathrm{~h}$ exposure to each different target freezing temperature varying between -3 and $-24{ }^{\circ} \mathrm{C}$ (Tab. II). Based on preliminary freezing tests, we optimized the limited availability of plant material and kept the duration of the whole experiment to a minimum ( 6 days), therefore reducing possible effects of differences in seedling hardening conditions.

Membrane injury was determined by measuring the conductivity of the incubation solution where the ions leak from the cells after artificial freezing. After thawing, $15 \mathrm{~mL}$ of deionised water were 
Table II. Target freezing temperatures tested per species and needle types (P: primary, S: Secondary). Asterisks represent the tested combinations.

\begin{tabular}{|c|c|c|c|c|c|c|c|c|c|c|c|c|c|c|}
\hline \multirow[b]{2}{*}{ Species } & \multirow[b]{2}{*}{ Needle type } & \multicolumn{13}{|c|}{ Test temperature } \\
\hline & & -3 & -4 & -5 & -6 & -8 & -10 & -12 & -14 & -16 & -18 & -20 & -22 & -24 \\
\hline \multirow{2}{*}{ P. canariensis } & $\bar{P}$ & $*$ & $*$ & $*$ & $*$ & $*$ & $*$ & $*$ & & & & & & \\
\hline & S & $*$ & $*$ & $*$ & $*$ & $*$ & $*$ & $*$ & $*$ & & & & & \\
\hline \multirow{2}{*}{ P. radiata } & $\mathrm{P}$ & $*$ & $*$ & $*$ & $*$ & $*$ & $*$ & $*$ & $*$ & $*$ & $*$ & & & \\
\hline & S & $*$ & $*$ & $*$ & $*$ & $*$ & $*$ & $*$ & $*$ & $*$ & $*$ & & & \\
\hline \multirow{2}{*}{$P$. pinea } & $\mathrm{P}$ & $*$ & $*$ & $*$ & $*$ & $*$ & $*$ & $*$ & $*$ & $*$ & * & & & \\
\hline & S & $*$ & $*$ & $*$ & $*$ & $*$ & $*$ & $*$ & $*$ & $*$ & $*$ & & & \\
\hline \multirow{2}{*}{ P. halepensis } & $\mathrm{P}$ & $*$ & $*$ & $*$ & $*$ & $*$ & $*$ & $*$ & $*$ & $*$ & $*$ & & & \\
\hline & S & $*$ & $*$ & $*$ & $*$ & $*$ & * & $*$ & $*$ & $*$ & $*$ & & & \\
\hline \multirow{2}{*}{ P. brutia } & $\mathrm{P}$ & $*$ & $*$ & $*$ & $*$ & $*$ & $*$ & $*$ & $*$ & $*$ & $*$ & $*$ & & \\
\hline & S & $*$ & $*$ & $*$ & $*$ & $*$ & $*$ & $*$ & $*$ & $*$ & $*$ & $*$ & $*$ & \\
\hline \multirow{2}{*}{$P$. pinaster } & $\mathrm{P}$ & & & & $*$ & $*$ & $*$ & $*$ & $*$ & $*$ & $*$ & $*$ & $*$ & \\
\hline & $S$ & & & & $*$ & $*$ & $*$ & $*$ & $*$ & $*$ & $*$ & $*$ & $*$ & $*$ \\
\hline \multirow{2}{*}{ P. nigra } & $\mathrm{P}$ & & & & & & & $*$ & $*$ & $*$ & $*$ & $*$ & $*$ & $*$ \\
\hline & $S$ & & & & & & & $*$ & $*$ & $*$ & $*$ & $*$ & $*$ & $*$ \\
\hline P. sylvestris & $\mathrm{S}$ & & & & & & & * & * & * & $*$ & $*$ & $*$ & * \\
\hline
\end{tabular}

Table III. ANOVA table corresponding to the general linear model for the Logit-transfomed values of It.

\begin{tabular}{|c|c|c|c|c|c|}
\hline & SS & $\overline{\mathrm{df}}$ & MS & $\mathrm{F}$ & $\mathrm{P}$ \\
\hline Temperature & 1001.147 & 1 & 1001.147 & 695.153 & 0.000000 \\
\hline Temperature $\times$ Species & 0.115 & 1 & 0.115 & 0.08 & 0.777391 \\
\hline Temperature $\times$ Needle & 7.703 & 2 & 3.851 & 2.6742 & 0.070072 \\
\hline Temperature $\times$ Needle $\times$ Species & 45.69 & 7 & 6.527 & 4.5322 & 0.000067 \\
\hline Error & 639.441 & 444 & 1.44 & & \\
\hline
\end{tabular}

added to each tube containing needle samples and electrolyte conductivity was measured after $24 \mathrm{~h}$ at $25^{\circ} \mathrm{C}\left(C_{1}\right)$ with a K220 conductivity meter (Consort, Turnhout, Belgium). The samples were then boiled in an autoclave at $120{ }^{\circ} \mathrm{C}$ for $10 \mathrm{~min}$, held at $25^{\circ} \mathrm{C}$ for $12 \mathrm{~h}$ and total electrolyte conductivity was measured $\left(C_{2}\right)$. The relative cell damage at each target freezing temperature $\left(R_{\mathrm{t}}\right)$ was obtained as $R_{\mathrm{t}}=\left(C_{1} / C_{2}\right) \times 100$. In addition, the relative cell damage of the unfrozen control samples $\left(R_{0}\right)$ was determined. The Relative Index of freeze injury $\left(I_{\mathrm{t}}\right)$ was then calculated as $I_{\mathrm{t}}=\left(R_{\mathrm{t}}-R_{0}\right) /\left(1-R_{0}\right)$, according to (Flint et al., 1967). Values of $I_{\mathrm{t}}$ close to 0 represent no cell injury while values close to 1 indicate total cell damage.

\subsection{Data analysis}

A Logit transformation was applied to the $I_{\mathrm{t}}$ values, and subsequently, a general linear model (GLM) including the effects of temperature (as a covariate), species and needle type within species (both as categorical fixed effects) was adjusted. In the model, the interactions of temperature with the fixed effects reflected differences in the slopes of regression models of the Relative Index of Freeze Injury versus temperature due to each effect. In addition, maximum likelihood-based methods were used to fit a logistic model to each temperature-It combination per individual and needle type, and the temperature corresponding to an $I_{\mathrm{t}}$ of $50 \%$ (inflexion point of the logistic model) was then obtained. We assumed that this value corresponded to the death of $50 \%$ of needle tissues, referred to as lethal temperature for 50\% injury (LT50), and therefore we used this value as an estimator of freezing tolerance. The means and $95 \%$ confidence intervals were calculated per species and needle type. Standard Pearson's correlations and linear standard regressions were used to assess the relationship between LT50 of primary and secondary needles, and between LT50 and LMA and the climate variables of the species. All statistical tests were done using the SAS statistical package version No. 8.2 (SAS Institute, Cary, North Carolina, USA).

\section{RESULTS}

\subsection{Freezing injury in primary and secondary needles}

Neither the species nor the needle type on their own affected significantly the slopes of the linearized models between temperature and the logit-transformed relative index of freeze injury, $I_{\mathrm{t}}$ (Tab. III). By contrast, needle type within species, represented by the triple interaction (Temperature $\times$ Needle $\times$ Species) was highly significant ( $p=0.000067)$. This means that the response of the samples to the controlled freezing test was largely dependant on the primary/mature condition of the needles for each species. The whole model explained $72 \%$ of the observed variation $(71 \%$ adjusted to number of variables in the model, with $p<0.001)$.

The logistic curves of relative index of freeze injury $\left(I_{\mathrm{t}}\right)$ as a function of the temperature (Fig. 3) showed this variation between species and needle types within species, with LT50 values ranging from $-6.6^{\circ} \mathrm{C}$ to $-23.0^{\circ} \mathrm{C}$ (Fig. 4).

Primary needles showed significantly higher LT50 values (lower freezing tolerance) than secondary needles for four of 

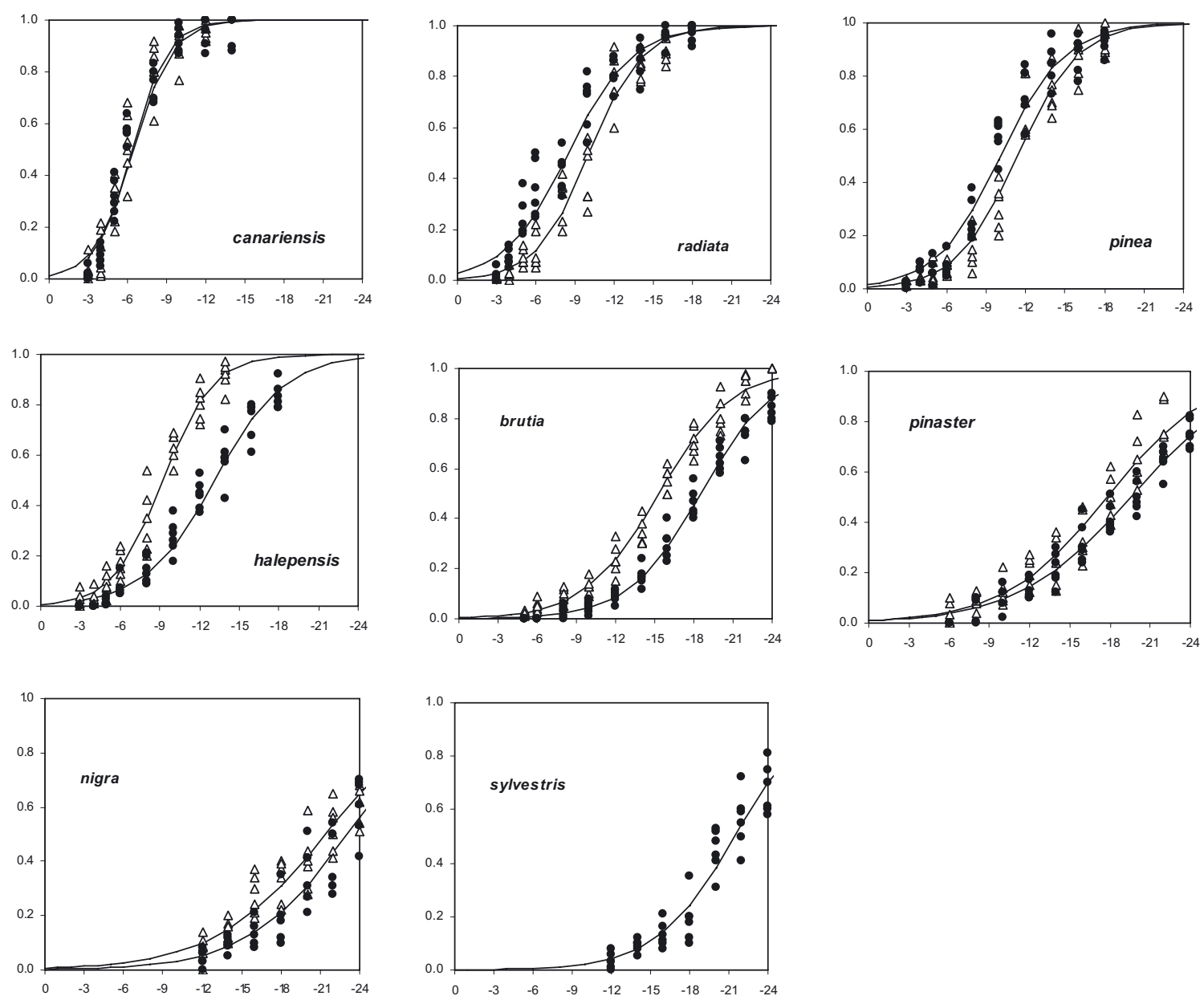

Figure 3. Relative index of freeze injury $\left(I_{\mathrm{t}}, y\right.$ axis) versus test temperatures ( $x$ axis)and fitted logistic curves for the eight species analyzed. Data for primary needles (white triangles) and secondary needles (black dots).

the studied species, $P$. halepensis, $P$. brutia, $P$. pinaster and $P$. nigra, while both needle types performed similarly for $P$. $c a$ nariensis, $P$. pinea and $P$. radiata (Fig. 4). Moreover, the correlation of freezing injury between both leaf types was very high (Pearson's $r=0.94 ; p=0.0007$ ). It is worthwhile noting that the three species which showed similar freezing tolerance in primary and secondary needles were also those showing the higher LT50, with mean values occurring between -6 and $-12{ }^{\circ} \mathrm{C}$.

\subsection{LMA and ecological correlations with LT50}

While LMA was higher in secondary needles for all studied species (although the difference was non-significant for P. halepensis, Fig. 5), there was a total absence of correlation between LMA and LT50 for both primary and secondary needles. By contrast, the correlation between freezing tolerance and the mean temperature of the coldest month of the seed source was very strong for both primary and for secondary needles (Fig. 6). Both correlations and adjusts of linear regression model were slightly stronger for secondary needles compared to primary needles $\left(r^{2}=0.93, p=0.00005\right.$ and $r^{2}=0.88, p=0.0009$, respectively) but in the first case, there is one more data point corresponding to $P$. sylvestris.

\section{DISCUSSION}

Differences in freezing tolerance both between species and needle developmental phases are due to different physiological capacities of cold acclimation, namely in carbohydrates metabolism, membranes characteristics and specific antifreeze proteins (Larcher, 2005) that have been adaptively selected for each species and ecotype (Repo et al., 2000; Savolainen et al., 2004). Without exploring the mechanisms underlying different freezing tolerance, our experiment showed that primary needles tended to be equally or more sensitive to freezing injury when compared to secondary needles of the same plants, but this difference is species-dependent among the seven pines 


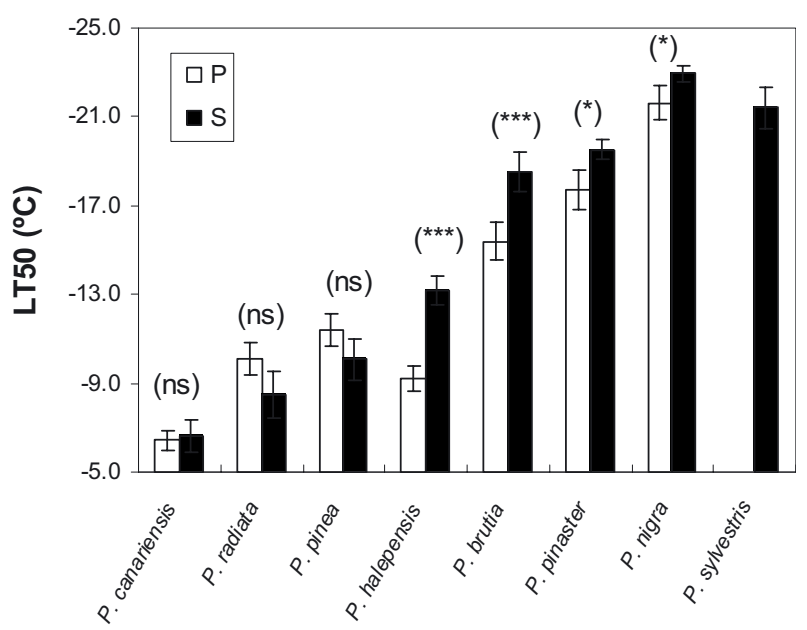

Figure 4. Comparison of LT50 between primary (P) and secondary (S) needles per species. Means and 95\% confidence intervals from $n=6$ individuals per species. $(* * * P<0.001$, ** $P<0.01, * P<$ 0.05 , ns non-significant).

analyzed. Furthermore, the differences encountered among species for both needle types prior to winter acclimation were highly related to their climate of origin.

\subsection{Differences between primary and secondary needles}

The Eurosiberian $P$. nigra and the Mediterranean $P$. pinaster, $P$. brutia and $P$. halepensis had secondary needles more frost tolerant than primary needles, while $P$. canariensis, $P$. pinea and $P$. radiata had secondary and primary needles equally frost-sensitive. It is worthy of note that these three species were also the less tolerant to freezing, while those with more different behavior between foliage types (this is, $P$. halepensis and P. brutia) had intermediate frost tolerance values. Finally, the more tolerant species $P$. pinaster and $P$. nigra showed a slightly higher (but still significant) tolerance of secondary needles.

In the last two Pinus sp. (and to a lesser extent in P. brutia), secondary needles appear normally during the very first vegetative period, unlike the thermophyllic, Mediterranean pines sensu stricto (this is, taking apart $P$. radiata, (Klaus, 1989) and author's unpublished data). In the moderately cold habitats where these species grow, these precocious, more tolerant secondary needles can ensure maintaining enough photosynthesis during the first winters.

On the other extreme, $P$. canariensis and $P$. pinea primary needles can be the only photosynthetic biomass for several years due to their much delayed shoot ontogeny (Climent et al., 2006; Klaus, 1989). In the Canary Islands pine, this developmental delay has been interpreted as necessary for accumulating sufficient root biomass and attaining a critical size before starting to form the highly sclerophyllous secondary foliage (as LMA values show) under a limiting dry environment. Anatomical differences suggest that primary needles can have a higher photosynthetic efficiency than secondary nee-

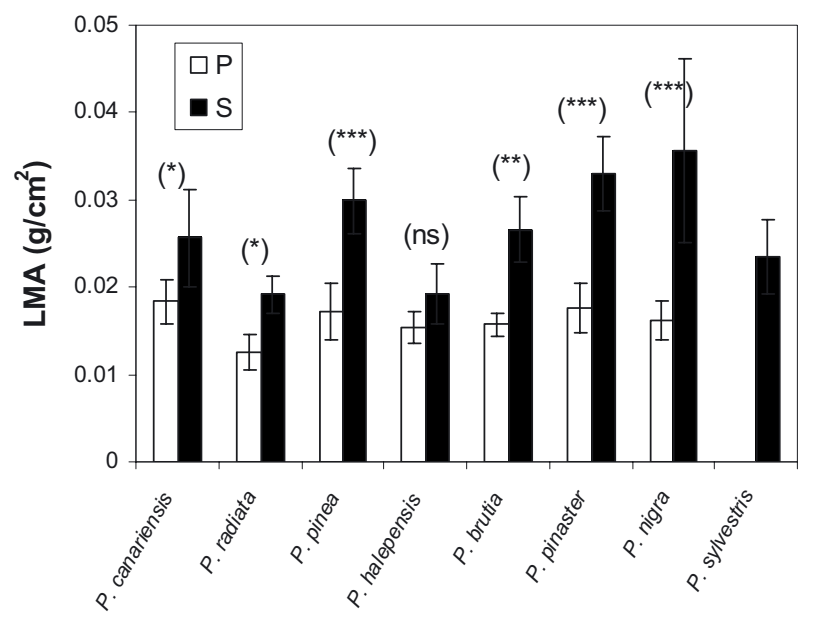

Figure 5. Comparison of needle mass per area (LMA) between primary $(P)$ and secondary $(\mathrm{S})$ needles per species. Means and $95 \%$ confidence intervals from $n=6$ individuals per species. (*** $P<0.001$, ** $P<0.01, * P<0.05$, ns non-significant).

dles (Jimenez et al., 2000), which was confirmed in Juniperus occidentalis (Miller et al., 1995) but still not investigated in pines. However, while previous research have shown that secondary needles have a significantly lower cuticular transpiration than primary needles in this species (Climent et al., 2006), our experiment revealed similar susceptibility to frost injury which suggest different tolerance pathways between drought and cold. The mild winter temperatures characterizing the natural area of this species, even at high altitudes (Luis et al., 2007) are not likely to have exerted any selection towards frost tolerance at any developmental stage. By contrast, many natural forests of $P$. pinea occur in relatively cold areas in flat continental dune deposits in inner Spain (precisely the tested provenance is one of them), where moderate radiation frosts are frequent from October to May (Mutke et al., 2003). Considering the formerly mentioned ontogenetic delay, it makes sense that primary needles are (at least) as tolerant to frost stress as secondary needles. A similar explanation has been postulated in the comparison of juvenile and adults in colonizing Nothofagus broadleaved species (Meza-Basso et al., 1986).

The third species with similarly low tolerance of primary and secondary needles was $P$. radiata. The similarly low frost resistance between seedlings and saplings of this species had been already stated (Greer et al., 1989). These results are coherent with the mild conditions along the species natural distribution (with a mean temperature of the coldest month of about $10.5^{\circ} \mathrm{C}$, very similar to that of $P$. canariensis). Interestingly, while secondary needles in this species are relatively precocious in the plant ontogeny, primary needles can continue forming for several years like in the Mediterranean pines sensu stricto, such that both needle types coexist widely in time and space in seedlings. This relevant fact seems to be inexplicably absent from the abundant scientific literature of shoot phase change and its hormonal control, apart from some early comments (Lester, 1968), but its possible adaptive meaning merits investigation. 

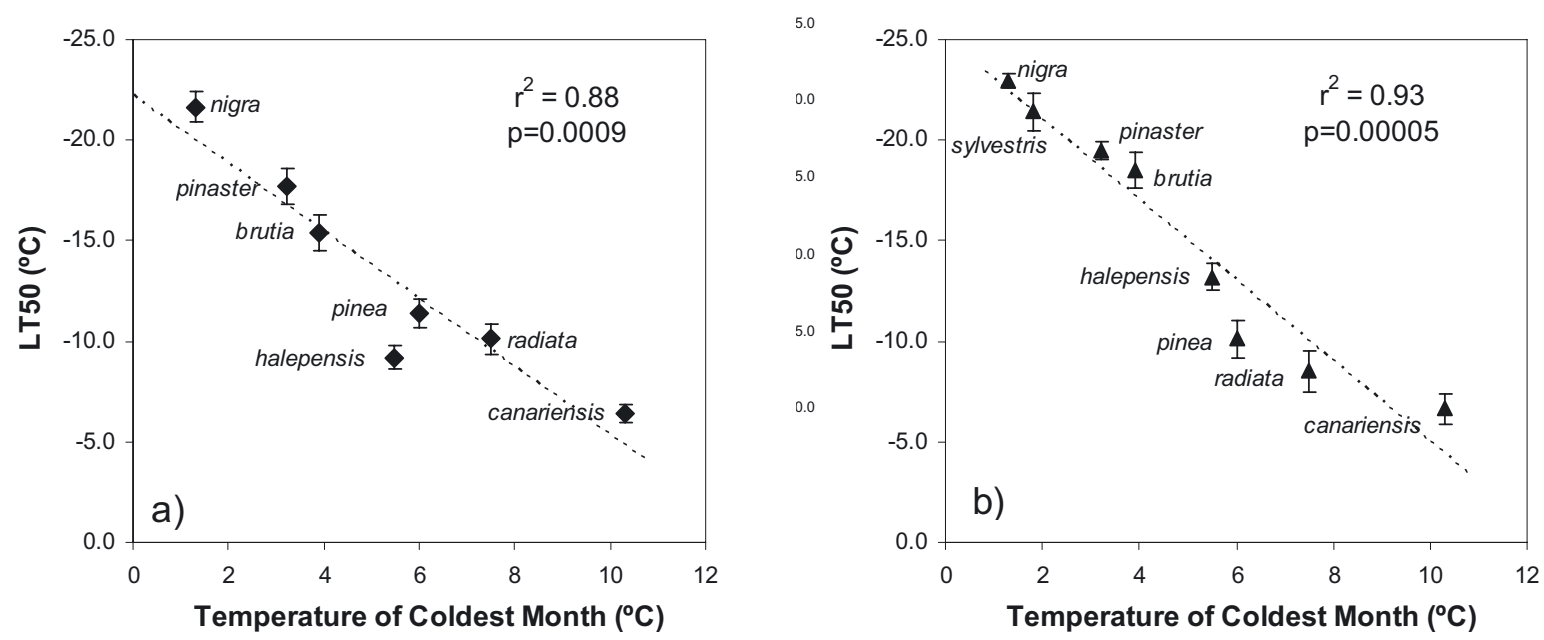

Figure 6. Relationship between mean temperature of the coldest month at the seed source (averaged within each species' provenance) and LT50. (a) Primary needles and (b) secondary needles. LT50 data points represent means and bars represent $95 \%$ confidence intervals for $n=6$ individuals per species.

Pinus halepensis was the only studied species that combined a marked differentiation of frost tolerance between primary and secondary foliage with a delayed ontogeny (i.e. delayed formation of secondary needles). Also, the marked differentiation between foliage types in frost tolerance does not mimic the similarity of LMA values. This pine grows in Mediterranean dry slopes at low to mid altitudes, where it competes with woody formations of variable density and vigour (garriga, makis or phrygana) benefiting of its high colonizing ability after fires (Tapias et al., 2004). In these predominantly convex areas, frosts are infrequent and mostly caused by the advection associated to northerly cold spells, rather than from radiation (Lindkvist et al., 2000). Therefore, woody shrubs might provide enough shelter for frost-sensitive seedlings with juvenile foliage for a few years, before hardier, secondary needles are formed at higher levels of the plant (Langvall and Ottosson-Löfvenius, 2002). This rarity of frosts at the ground level in the typical Aleppo pine habitat runs in parallel to the lack of cold acclimation in the roots of this species (Tinus et al., 2000).

\subsection{Ecological correlations and evolutionary implications}

The variation pattern of freezing injury amongst the eight pine species studied was highly consistent with each species' thermal ecological niche. Considering secondary needles, two groups of species can be identified; the four that presented LT50 lower than $-17{ }^{\circ} \mathrm{C}(P$. nigra, $P$. sylvestris, $P$. pinaster and $P$. brutia) and the other four that shown more heterogeneous and lower tolerances (LT50 of -6 to $-14{ }^{\circ} \mathrm{C}$, P. halepensis, P. pinea, $P$. radiata and $P$. canariensis). For primary needles, the variation pattern between species is more continuous, but the species ranking is highly concordant. These two groups can be directly related with the selection exerted by the contrasting thermal environments that these species encounter: mountain and inland pines face severe and frequent frosts; in opposition, coastal Mediterranean areas are characterized by a variable climate where cold spells are infrequent and/or less severe.

Pinus sylvestris is generally considered a more coldtolerant species compared to P. nigra, based on their distributional areas and confirmed by experimental data (Strimbeck et al., 2007). However our experiment showed a very similar response of secondary needles, with even a slightly higher frost tolerance for P. nigra. This result is consistent with the mean temperature of the coldest month at the origin of the provenance chosen (Fig. 5B), despite a higher mean annual temperature in the $P$. nigra provenance.

The significantly higher freezing tolerance for needles of $P$. brutia compared to P. halepensis - despite being genetically close - is in accordance with the higher general cold tolerance of the first species and their niche segregation in the Eastern Mediterranean (Bariteau, 1992). Moreover, the abovementioned difference of habitats between $P$. pinea and $P$. halepensis justify the inversion of their ranking in freezing tolerance for primary ( $P$. pinea more tolerant than $P$. halepensis) and secondary needles (the opposite ranking, Figs. 4 and 6).

As already mentioned, the distinct high susceptibility to freezing injury of $P$. canariensis needles is in accordance with the very low influence of frosts within its natural habitat (Luis et al., 2007). This pine is considered a living fossil, survivor of the thermophyllic Tertiary flora, whose fossil remains have been found in several locations from continental Europe (Klaus, 1989). During the Pleistocene, it was probably displaced from higher latitudes and altitudes by species that were capable of developing greater frost tolerance (Sakai, 1971). 
The variation encountered between species and between foliage types within species is highly coherent with our knowledge on their ecology and can help to direct future experiments. In particular, the effects of phenological shifts in Old World's hard pines driven by warmer winters under the ongoing Global Change (e.g. a delay in bud set in autumn) can be better explained if the inherent differences between foliage types, linked to each species ontogenetic features, are taken into account.

Acknowledgements: This research is part of the project AT-05 002 (INIA) and AGL2005-07440 REPROFOR (CYCIT). Thanks to S. Iglesias, J. Peñuelas and J.L. Nicolas (Spanish Directorate for Biodiversity DGB) for providing the seeds, to F. Salgado, I. Santos and G. Ruiz (TRAGSA, Spain), for their work at the nursery and to N. Godoy, S. Herrera and F. del Caño (INIA, Madrid) for leaf area measurements. Thanks to H. Merouani at (ISA, Lisbon).

\section{REFERENCES}

Alía R., Moro J., and Denis J.B., 1997. Perfomance of Pinus pinaster provenances in Spain: interpretation of the genotype by environment interaction. Can. J. For. Res. 27: 1548-1559.

Bannister P., Colhoun C.M., and Jameson P.E., 1995. The winter hardening and foliar frost resistance of some New Zealand species of Pittosporum. N. Z. J. Bot. 33: 409-414.

Bariteau M., 1992. Geographic-variation and stress-adaptation of Pinus halepensis - Pinus brutia complex in Mediterranean conditions Preliminary results of a provenance test in France. Ann. Sci. For. 49: 261-276.

Blodner C., Skroppa T., Johnsen O., and Polle A., 2005. Freezing tolerance in two Norway spruce (Picea abies [L.] Karst.) progenies is physiologically correlated with drought tolerance. J. Plant Physiol. 162: 549-558.

Boorse G.C., Ewers F.W., and Davis S.D., 1998. Response of chaparral shrubs to below-freezing temperatures: Acclimation, ecotypes, seedlings vs. adults. Am. J. Bot. 85: 1224-1230.

Climent J., Chambel M.R., López R., Mutke S., Alía R., and Gil L., 2006. Population divergence for heteroblasty in the Canary Islands pine (Pinus canariensis, Pinaceae). Am. J. Bot. 93: 840-848.

Darrow H.E., Bannister P., Burritt D.J., and Jameson P.E., 2001. The frost resistance of juvenile and adult forms of some heteroblastic New Zealand plants. N. Z. J. Bot. 39: 355-363.

Erickson R.O. and Michelini F.J., 1957. The Plastochron Index. Am. J. Bot. 44: 297-305.

Flint H.L., Boyce B.R., and Beattie D.J., 1967. Index of injury - a useful expression of freezing injury to plant tissues as determined by electrolytic method. Can. J. Plant Sci. 47: 229-230.

Greer D.H., Stanley C.J., and Warrington I.J., 1989. Photoperiod control of the initial phase of frost hardiness development in Pinus radiata. Plant Cell Environ. 12: 661-668.

Hijmans R.J., Cameron S.E., Parra J.L., Jones P.G., and Jarvis A., 2005. Very high resolution interpolated climate surfaces for global land areas. Int. J. Climatol. 25: 1965-1978.

IPCC. 2007. Climate change 2007: The physical science basis. Contribution of working group $i$ to the fourth assessment report of the intergovernmental panel on climate change (IPCC), Cambridge University Press, Cambridge (UK), p. 396.

Jimenez S., Zellnig G., Stabentheiner E., Peters J., Morales D., and Grill D., 2000. Structure and ultrastructure of Pinus canariensis needles. Flora 195: 228-235.

Jones C.S., 1999. An essay on juvenility, phase change, and heteroblasty in seed plants. Int. J. Plant Sci. 160: S105-S111.
Klaus W., 1989. Mediterranean pines and their history. Plant Syst. Evol. 162: $133-163$

Langvall O. and Ottosson-Löfvenius M., 2002. Effect of shelterwood density on nocturnal near-ground temperature, frost injury risk and budburst date of Norway spruce. For. Ecol. Manage. 168: 149-161.

Larcher W., 2000. Temperature stress and survival ability of Mediterranean sclerophyllous plants. Plant Biosyst. 134: 279-295.

Larcher W., 2005. Climatic constraints drive the evolution of low temperature resistance in woody plants. J. Agric. Meteorol. 61: 189-202.

Lester D., 1968. Developmental patterns of axillary meristematic activity in seedlings of Pinus. Bot. Gaz. 129: 206-210.

Lindkvist L., Gustavsson T., and Bogren J., 2000. A frost assessment method for mountainous areas. Agric. For. Meteorol. 102: 51-67.

López R., Zehavi A., Climent J., and Gil L., 2007. Contrasting ecotypic differentiation for growth and survival in Pinus canariensis (Pinaceae). Aust. J. Bot. 55: 1-11.

Luis V., Taschler D., Hacker J., Jiménez M.S., Wieser G., and Neuner G., 2007. Ice nucleation and frost resistance of Pinus canariensis seedlings bearing needles in three different developmental states. Ann. For. Sci. 64: 177-182.

Meza-Basso L., Guarda P., Rios D., and Alberdi M., 1986. Changes in free amino acid and frost resistance in Nothofagus dombeyi leaves. Phytochemistry 25: 1843-1846.

Miller P.M., Eddleman L.E., and Miller J.M., 1995. Juniperus occidentalis juvenile foliage: advantages and disadvantages for a stresstolerant, invasive conifer. Can. J. For. Res. 25: 470-479.

Mutke S., Gordo J., Climent J., and Gil L., 2003. Shoot growth and phenology modelling of grafted stone pine (Pinus pinea L.) in inner Spain. Ann. For. Sci. 60: 527-537.

Palacio S., Milla R., and Montserrat-Martí G., 2005. A phenological hypothesis on the thermophilous distribution of Pistacia lentiscus $\mathrm{L}$. Flora 200: 527-534.

Pardos M., Calama R., and Climent J., 2008. Difference in cuticular transpiration and sclerophylly in juvenile and adult pine needles relates to the species-specific rates of development. Trees DOI: 10.1007/s00468-008-0296-6.

Repo T., Zhang G., Ryyppo A., Rikala R., and Vuorinen M., 2000. The relation between growth cessation and frost hardening in Scots pines of different origins. Trees 14: 456-464.

Sakai A., 1971. Freezing resistance of relicts from Arcto-Tertiary flora. New Phytol. 70: 1199-1205.

Sakai A. and Larcher W., 1987. Frost survival of plants. Responses and adaptation to freezing stress. Ecological and studies: analysis and synthesis, Vol. 62, Springer.

Savolainen O., Bokma F., García-Gil R., Komulainen P., and Repo T., 2004. Genetic variation in cessation of growth and frost hardiness and consequences for adaptation of Pinus sylvestris to climatic changes. For. Ecol. Manage. 197: 79-89.

Shelbourne C.J.A., Burdon R.D., Bannister M.H., and Thulin I.J., 1979. Choosing the best provenances of radiata pine for different sites in New Zealand. N. Z. J. For. 24: 288-300.

Strimbeck G., Kjellsen T., Schaberg P., and Murakami P., 2007. Cold in the common garden: comparative low-temperature tolerance of boreal and temperate conifer foliage. Trees 21: 557-567.

Tapias R., Climent J., Pardos J.A., and Gil L., 2004. Life histories of Mediterranean pines. Plant Ecol. 171: 53-68.

Taylor P.A., 1970. A model of airflow above changes in surface heat flux, temperature and roughness for neutral and unstable conditions. Boundary-Layer Meteorology 1: 18-39.

Tinus R.W., Burr K.E., Atzmon N., and Riov J., 2000. Relationship between carbohydrate concentration and root growth potential in coniferous seedlings from three climates during cold hardening and dehardening. Tree Physiol. 20: 1097-1104.

Winn A.A., 1999. The functional significance and fitness consequences of heterophylly. Int. J. Plant Sci. 160: S113-S121. 